\title{
A Survey for Common Tobacco- and Pepper- Mosaic Viruses in the Filler-Tobacco Area of Puerto Rico
}

\author{
J. Enrique Pérez, José Adsuar, and E. A. Padilla \\ INTRODUCTION
}

For many years tobacco-mosaic virus has been the cause of severe losses to tobacco growers in Puerto Rico. Other viruses which are known to affect tobacco in Puerto Rico are the "mottle" mosaic (Puerto Rican pepper-mosaic virus) $(6),{ }^{2}$ etch virus (1), and leaf-curl. In a recent publication Adsuar and López (2) have shown that common tobacco mosaic and "mottle" have an appreciable effect on the yield of tobacco variety Virginia 12. Since tobacco mosaic and mottle are the most prevalent and harmful virus diseases of tobacco it seemed of importance to determine by a survey of the filler-tobacco regions of the Island the extent and incidence of both mosaics, as well as the presence of any other virus, using the usual infectivity tests and serological methods. Serological methods can also be used in determining the presence of these viruses in tobacco $(3,5)$.

\section{OBJECTIVES}

The purpose was to determine whether, by the use of both methods, a larger number of positives would be found and therefore a more complete picture of the extent of infection obtained.

\section{THE SURVEY}

The survey was carried out during a period of 3 years beginning in January 1952 and ending in April 1955. Only the Filler-Tobacco Area of Puerto Rico was included. This Area lies in the central part of the Island and includes the municipalities of Caguas, San Lorenzo, Cayey, Cidra, Aibonito, Barranquitas, Comerio, Naranjito, Orocovis, Morovis, Ciales, and Utuado. A total of 76 counties (barrios) were covered in these municipalities. The area surveyed is shown in figure 1.

Trips were made to the area to be surveyed two or three times a week during the tobacco-growing season for collection of tobacco samples; these were brought to the laboratory for infectivity and serological tests.

'Bacteriologist, Phytopathologist, and Research Assistant in Bacteriology, respectively, Agricultural Experiment Station, University of Puerto Rico, Río Piedras, P. R.

2 Italic numbers in parentheses refer to Iiterature Cited, p. 24. 


\section{EXPERIMENTAL PROCEDURE}

Samples were collected as follows: Three or four leaves were collected from a plant showing symptoms of mosaic, placed in a paper bag, and the bag labeled with the number of the specimen and the name of the town and county (barrio) where collected. The samples were then brought to the laboratory and tested for the presence of tobacco-mosaic and peppermosaic viruses by the infectivity test (plant-host reactions), and also serologically by means of a precipitin test. If samples could not be tested at once they were kept in a "deep-freeze" for a few days until tests could be made.

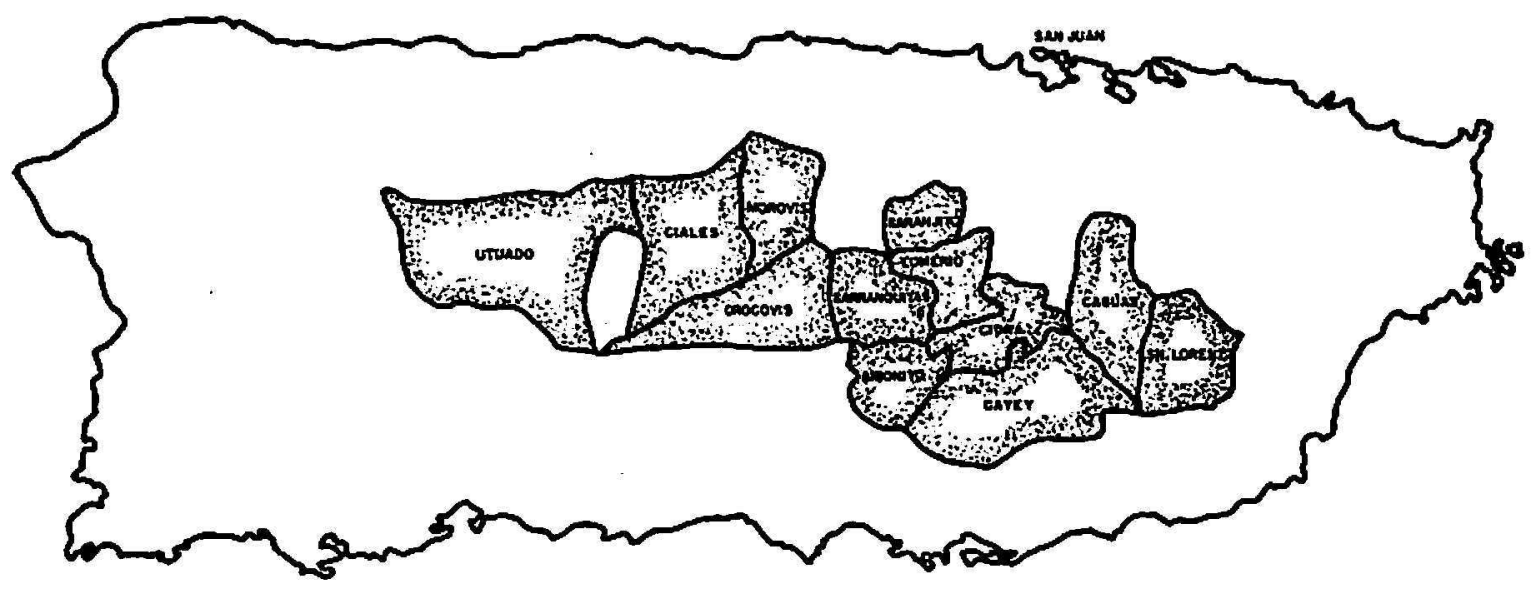

Frg. 1.-Map of the Filler-Tobacco Area of Puerto Rico.

\section{INFLC'IVITY TESTS}

Samples were ground in mortars, a thoroughly washed and dried mortar being used for each sample. The ground pulp was wrung through two layers of gauze and the sap collected in a test tube. The crude sap was then centrifuged at about 3,500 r.p.m. for 20 minutes for clarification. A portion was kept for the precipitin test and another portion was inoculated to small tobacco plants having the NN factor, and also to the Large Bell Hot variety of commercial pepper (6). The carborundum method was used.

The appearance of necrotic spots in 1 to 3 days on the NN tobacco leaves was interpreted as indicative of infection with tobacco-mosaic virus in the sample tested. The production of systemic veinal necrosis in Large Bell Hot pepper was taken as proof of infection with the common field strain of Puerto Rican pepper-mosaic virus.

\section{SEROLOGICAL TESTS}

At the beginning of the survey several methods were tried to determine the most accurate and economical one to be employed in the serological testing of the samples. The slide-agglutination test, in which a drop of crude 
sap is mixed with dilute antiserum and another drop with normal serum on a slide, was tested with the first 100 samples, together with the ring test (4) and the technique described below. It was found that the slide-agglutination test was subject to many nonspecific reactions. Special difficulty was encountered with the more darkly colored saps in the ring test, it being almost impossible to read the reaction. Therefore, the technique described below was finally adopted as a standard for the whole series of tests.

Antisera which reacted specifically with Puerto Rican pepper-mosaic virus were prepared by injecting rabbits with a partly purified preparation of the virus. Antisera for common tobacco-mosaic virus were prepared by injecting rabbits with a purified preparation of virus isolated locally. The sera were diluted to a $1 / 5$ or $1 / 10$ concentration in 0.85 -percent saline and

TABLE 1.-Reaction of tobarco samples to serological and infectivity tests for tobacco-mosaic and pepper-mosaic viruses

\begin{tabular}{|c|c|c|c|c|c|}
\hline $\begin{array}{c}\text { Total } \\
\text { number of } \\
\text { samples } \\
\text { tested for- }\end{array}$ & $\begin{array}{l}\text { Positive by } \\
\text { both tests }\end{array}$ & $\begin{array}{l}\text { Positive by } \\
\text { infectivity } \\
\text { test only }\end{array}$ & $\begin{array}{l}\text { Positive by } \\
\text { serology only }\end{array}$ & Total positives & $\begin{array}{l}\text { Negative by } \\
\text { both tests }\end{array}$ \\
\hline $\begin{array}{c}\text { Pepper- } \\
\text { mosaic } \\
\text { virus: } \\
952 \\
\text { Tobacco- } \\
\text { mosaic } \\
\text { virus: } \\
006\end{array}$ & $\begin{array}{l}37 \\
(3.8 \text { percent }) \\
534 \\
(58.5 \text { per- } \\
\text { cent) }\end{array}$ & $\begin{array}{l}32 \\
(3.3 \text { percent }) \\
141 \\
(15.4 \text { per- } \\
\text { (cent) }\end{array}$ & $\begin{array}{l}96 \\
(10 \text { per- } \\
\text { cent }) \\
14 \\
(1.5 \text { per- } \\
\text { cent })\end{array}$ & $\begin{array}{l}165 \\
(17.1 \text { per- } \\
\text { cent }) \\
689 \\
(75.4 \text { per- } \\
\text { cent })\end{array}$ & $\begin{array}{ll}787 & \\
(82.6 & \text { per- } \\
\quad \text { cent }) & \\
217 & \\
(23.7 & \text { per- } \\
\text { cent }) & \end{array}$ \\
\hline
\end{tabular}

about $0.25 \mathrm{ml}$. of each diluted serum placed in a $6 \times 50-\mathrm{mm}$. tube with the aid of a capillary pipette. Approximately an equal volume of clarified sap was then mixed with each serum and the mixtures were incubated at $40^{\circ} \mathrm{C}$. for 1 to 2 hours. Usually, 20 to 30 tobacco samples were thus tested simultaneously in a single day. The following control mixtures were always included with each series of tests: Clarified sap from each sample mixed with an equal volume of saline for control of nonspecific precipitation; tobaccomosaic virus plus its antiserum; tobacco-mosaic antiserum plus normal tobacco sap; pepper-mosaic virus plus its antiserum; pepper-mosaic antiserum plus normal tobacco sap.

\section{RESULTS}

Nine hundred and fifty-two tobacco samples were tested by the infectivity method and serologically by means of a precipitin test for the presence of pepper-mosaic virus. Of these $9 \overline{5} 2,906$ were also tested both ways for 
the presence of tobacco-mosaic virus. The results obtained by employing both methods of testing are shown in table 1 .

\section{DISCUSSION}

The results obtained in this survey by using the usual infectivity (planthost) method and a precipitin test for determining the presence of tobaccomosaic and pepper-mosaic viruses in tobacco bring out several interesting facts. It may be seen that both tests are complementary rather than confirmatory. If in testing for the presence of pepper-mosaic virus, for example, the infectivity test had been used exclusively, 10 percent of the total number of positives would have been missed. On the other hand if the precipitin test had been solely employed, 3.3 percent of positive specimens would have been missed and recorded as negative. As for tobacco-mosaic virus, if only the precipitin test had been employed, 15.4 percent of positives would have escaped.

The discrepancies and lack of complete correlation between the two tests merit some discussion. In the first place one has to consider that both tests do not measure the same things, a positive infectivity test being proof of the presence of infective virus particles, while the precipitin test indicates the presence of serologically active material specific to the virus or any of its strains. It is well known that virus particles may lose their infectivity while still retaining their serological activity. Likewise the serological activity may be lost while the infectivity is retained $(3)$. The serological activity of saps is correlated with the amount of virus present and the virus content of some saps may be too low to give any precipitation whatsoever.

A further comment is necessary regarding the tests for pepper-mosaic virus. Here the precipitin test gave an additional 10 percent of positives which were negative by the infectivity test. This 10 percent of positives did not give the characteristic reaction to pepper-mosaic virus on Large Bell Hot pepper described above but only mottling or even just vein clearing. This may indicate the existence of other strains of pepper mosaic which do not give the expected reaction in Large Bell Hot pepper.

\section{SUMMARY}

Results of a survey for the presence of tobacco-mosaic and pepper-mosaic viruses in the Filler-Tobacco Area of Puerto Rico, indicate that tobacco mosaic was the most prevalent, being present in a total of 75.4 percent of tobacco samples tested. Pepper-mosaic virus was found present in 17 percent of all samples tested. These results were obtained by employing both the usual infectivity (plant-host) method and precipitin tests. Complete correlation was not observed between the two kinds of tests, however and the 
results show that a larger number of positives is obtained by using both tests than by using either test alone.

\section{RESUMEN}

Los resultados de un catastro llevado a cabo para determinar la presencia del virus del mosaico del tabaco y del virus del mosaico del pimiento en la zona productora de tabaco de tripa en Puerto Rico, demuestran que el virus prevaleciente es el del mosaico del tabaco. Este se encontró en un total de 75.4 por ciento de las muestras de tabaco. El virus del mosaico del pimiento se encontró en 17 por ciento de todas las muestras.

Estos resultados se obtuvieron al emplearse el método corriente de reacciones en plantas hospedadoras (pruebas de infectividad) y el método de precipitinas con antisuero. No se observó una completa correlación entre las dos clases de prueba. Los resultados muestran que se encontró un mayor número de positivos al usarse ambas pruebas que si se hubiese usado una sola. Las dos pruebas, por lo tanto, se complementan entre sí.

\section{LITERATURE CITED}

1. Adsuar, J., and Pérez, J. Enrique, Cross-protection tests confirm the presence of Etch virus on tobacco in Puerto Rico, J. Agr. Univ. P. R. 40 (1) 83-4, 1956.

2. Adsuar, J., and López Matos, I., Reaction of some Nicotiana species to the pepperand common tobacco-mosaic viruses, $J$. Agr. Univ. P. R. 39 (3) 168-71, 1955.

3. Bawden, F. C., Serological reactions of plant viruses in: Plant Viruses and Virus Disenses, The Chronica Botanica Co., Waltham, Mass., 3rd edition, pp. 126-48, 1950.

4. Chester, K. S., Serological evidence in plant virus classification, Phylopath. 25 $686,1935$.

5. Pérez, J. Enrique, and Adsuar, J., Antigenic relationship between Puerto Rican pepper-mosaic virus and a strain of potato virus $\mathrm{Y}, J . A g r$. Univ. P. R. 39 (3) $165-7,1955$.

6. Roque, A., and Adsuar, J., Studies on the mosaic of peppers (Capsicum frutescens) in Puerto Rico, J. Agr. Univ. P. R. 25 (4) 1-11, 1941. 